\title{
Evolution of Avian coronavirus (AvCoV) in BHK-21 and VERO cells
}

\author{
Evolução de Coronavírus aviário (AvCoV) em células BHK-21 e VERO
}

\author{
Beatriz Alcântara Leite ${ }^{1}$; Sueli Akemi Taniwaki Miyagi1; Paulo Eduardo Brandão ${ }^{1}$ \\ ${ }^{1}$ Universidade de São Paulo, Faculdade de Medicina Veterinária e Zootecnia, Departamento de Medicina Veterinária Preventiva e \\ Saúde Animal, São Paulo - SP, Brazil
}

\begin{abstract}
Avian coronavirus (AvCoV) infects a range of tissues in chickens and several other avian species. Although the virus can be isolated in chicken embryos, only a few strains of the 6 genotypes/33 lineages can grow in cell lines, with the Beaudette strain (GI-1 lineage) being the most used for in vitro studies. Considering the differences between cell lines and chicken embryos as habitats for $\mathrm{AvCoV}$, this study aimed to assess the diversity of the genes coding for the nonstructural protein 3 (nsp3) and spike envelope protein (S) after serial passages in BHK-21 and Vero cells. After 14 passages of an embryo-adapted Beaudette strain, the virus loads fluctuated in both cell lines, with the highest loads being $8.72 \log$ genome copies/ $\mu \mathrm{L}$ for Vero and $6.36 \log$ genome copies/ $\mu \mathrm{L}$ for BHK-21 cells. No polymorphisms were found for nsp3; regarding S, not only aa substitutions (Vero: $8^{\text {th }}$ passage A150S, and 14th S150A; BHK-21: 4th S53F, 8th F53Y, and 8th S95R), but also minor variants could be detected on chromatograms with fluctuating intensities. As the regions of these aa substitutions are within the receptor-binding domain of $\mathrm{S}$, it can be speculated that differences in cell receptors between Vero and BHK-21 cells and the speed of cell death led to the selection of different dominant strains, while the stability of nsp3 supports its function as a protease involved in AvCoV replication. In conclusion, $\mathrm{AvCoV}$ quasispecies evolution is influenced by the biological model under consideration, and a gradual transition is seen for minor and major variants.
\end{abstract}

Keywords: Avian coronavirus. Spike. Nsp3. Evolution. Cell culture.

\section{RESUMO}

O Coronavírus aviário AvCoV infecta uma variedade de tecidos de galinhas e de outras espécies aviárias. Apesar de este vírus poder ser isolado em ovos embrionados de galinha, apenas alguns dos 6 genótipos / 33 linhagens podem crescer em cultivo celular, sendo a cepa Beuadette (linhagem GI-11) a mais utilizada para estudos in vitro. Considerando as diferentes linhagens celulares e ovos embrionados como habitats para o AvCoV, este estudo teve por objetivo estudar a diversidade de genes que codificam para a proteína não-estrutural 3 (nsp3) e espícula (S) após passagens seriadas em células BHK-21 e VERO. Após 14 passagens, de uma amostra Beuadette adaptada a ovos embrionados, os títulos virais variaram em ambas as células, com os maiores títulos sendo de 8,72 log cópias genômicas $/ \mu \mathrm{L}$ para Vero e 6,36 cópias genômicas/ $\mu \mathrm{L}$ para BHK-21. Nenhum polimorfismo foi encontrando para nsp3. Considerando a proteína $S$, não somente foram encontradas substituições de aminoácidos (Vero: $8^{a}$ passagem A150S e 14 a passagem S150A; BHK-21: $4^{\mathrm{a}}$ passagem S53F, 8 a passagem F53Y e S95R), mas também, variantes subconsensuais foram detectadas pelos cromatogramas com intensidades flutuantes. Uma vez que as regiões destes aa se encontram no domínio de ligação de receptor de $S$, pode-se especular que diferenças em receptores celulares entre Vero e BHK-21, além da velocidade da morte celular, levaram à seleção de diferentes cepas dominantes, enquanto que a estabilidade de nsp3 concorda com sua função como protease com papel na replicação de AvCoV. Como conclusão, a evolução de quase-espécies de AvCoV é influenciada pelo modelo biológico sob consideração e uma transição gradual é vista para variantes dominantes e subdominantes.

Palavras-chave: Coronavírus aviário. Espícula. Nsp3. Cultivo celular. 
Correspondence to:

Paulo Eduardo Brandão

Universidade de São Paulo, Faculdade de Medicina Veterinária

e Zootecnia, Departamento de Medicina Veterinária

Preventiva e Saúde Animal

Av. Prof. Dr. Orlando Marques de Paiva, 87, Butantã

CEP: 05508-270, São Paulo - SP, Brazil

e-mail: paulo7926@usp.br

Received: January 28, 2020

Approved: May 19, 2020

How to cite: Leite BA, Miyagi SAT, Brandão PE. Evolution of Avian coronavirus (AvCoV) in BHK-21 and VERO cells. Braz J Vet Res Anim Sci. 2020;57(2):e166086. https://doi. org/10.11606/issn.1678-4456.bjvras.2020.166086

\section{Introduction}

Infectious bronchitis virus (IBV) is the prototype host type in the species avian coronavirus (AvCoV) (Riboviria; Nidovirales; Cornidovirineae; Coronaviridae; Orthocoronavirinae; Gammacoronavirus; Igacovirus; Avian Coronavirus) and infects mainly chickens (Gallus gallus), causing avian infectious bronchitis (IB), an acute multisystemic disease of great economic impact on the poultry industry (Cavanagh, 2007; Colvero et al., 2015; Cook et al., 2012; International Committee on Taxonomy of Viruses, 2018; Sjaak de Wit et al., 2011). Its control is globally achieved through immunization with attenuated and killed vaccines, but novel variants emerge in cases of low vaccine coverage (Cavanagh, 2007; Colvero et al., 2015; Cook et al., 2012; Sjaak de Wit et al., 2011; Toro et al., 2012a, 2012b).

$\mathrm{AvCoV}$ is an enveloped virus with a +ssRNA genome of $27.6 \mathrm{~kb}$ in length with 10 open reading frames (ORFs) in the following order: 5'UTR-1a-1ab-S-3a-3b-E-M-5a-5b-N-3'UTR; the UTRs are untranslated regions (Cavanagh, 2007; Laconi et al., 2018). The replicase gene is in ORFs 1a and 1ab and is expressed as two polyproteins, ppla and pplab, which are cleaved into 15 nonstructural proteins (NSPs 2-16) (Cavanagh, 2007; Laconi et al., 2018). The genome also encodes four structural proteins, the spike glycoprotein (S), small membrane protein (E), integral membrane protein (M) and nucleocapsid protein $(\mathrm{N})$, and the accessory proteins $3 \mathrm{a}$, 3b, 5a, and 5b (Cavanagh, 2007; Laconi et al., 2018).

The genetic diversity of the virus is modulated by mutation and recombination, and this phenomenon can be promptly detected for the $\mathrm{S}$ protein, which is the basis for new serotypes (Cavanagh, 2007; Sjaak de Wit et al. 2011). The ectodomain of the $S$ protein is divided into the $S 1$ and S2 subunits, both of which are responsible for cell tropism (Bickerton et al., 2018; Casais et al., 2003). In S1, one can find the receptor-binding domain (RBD) with amino acids critical for attachment, where small variations in amino acids are enough to give rise to new variants (Cavanagh, 2007; Promkuntod et al., 2014; Sjaak de Wit et al. 2011).

Beaudette is an attenuated GI-1 type (Massachusetts) strain of $\mathrm{AvCoV}$ adapted to grow in Vero cells (green monkey kidney epithelial cells), making it a suitable model for studies on IBV evolution in vitro (Coria \& Ritchie, 1973; Cunningham et al., 1972; Yamada et al., 2009), but other cell lines, such as BHK-21 (baby hamster kidney cells) cells, are also used for IBV and other coronaviruses (Laconi et al., 2018).

This study was designed to gather data on IBV in vitro evolution, aiming to 1) compare the molecular evolution of S1 and the nsp3-coding regions, which have high and low evolutionary rates, respectively, after serial passages of the Beaudette strain in Vero and BHK-21 cells, 2) measure the effects of mutations on virus fitness, and 3) infer possible consequences of accumulated mutations on protein structures.

\section{Materials and Methods}

\section{Cells lines and virus}

The Vero and BHK-21 cell lines were grown in $25 \mathrm{~cm}^{2}$ cell culture flasks with minimum essential medium (MEM - Gibco ${ }^{\mathrm{Tm}}$ ) supplemented with $10 \%$ fetal bovine serum (FBS - Gibco ${ }^{\mathrm{Tn}}$ ) at $37^{\circ} \mathrm{C}$, and each passage was tested for Mycoplasma spp. using PCR (Nikfarjam \& Farzaneh, 2012; Young et al., 2010).

The Beaudette strain of IBV isolated in chicken embryos was used as a starting seed for the downstream experiments.

\section{Passages of the Beaudette strain in the cell lines}

Vero and BHK-21 cell monolayers at $>90 \%$ confluence in $25 \mathrm{~cm}^{2}$ flasks were used for serial passages of the Beaudette strain as follows: $i$. the growth medium was discarded; $i$. the inoculum or MEM (negative control) was added; iii. viral adsorption was allowed to occur at $37^{\circ} \mathrm{C}$ for $1 \mathrm{~h}$; $i v$. the inoculum or negative control MEM was discarded; $v$. $10 \mathrm{~mL}$ of MEM plus 10\% FBS was added to the monolayers, followed by incubation at $37^{\circ} \mathrm{C}$ for $48 \mathrm{~h}$; and $v i$. monolayers where frozen at $-80^{\circ} \mathrm{C}$, thawed and clarified at $1,000 \times \mathrm{g}$ for 5 minutes, with the supernatant used for the next passage.

As adaptive mutation plays an important role in cell-specific replication fitness, and to analyze this change in new host cells, passages were performed, providing two drastic changes in the environment for passage in Vero cells. From the original preparation (embryo-adapted Beaudette strain), the inoculum was passaged once on BHK-21 cells 
(first passage). Using this first passage, successive passages in BHK-21 cells (second to $14^{\text {th }}$ passage) and in Vero cells (first to $14^{\text {th }}$ passage) were performed.

\section{Determination of virus load}

Total RNA was extracted from all passages with a PureLink ${ }^{\mathrm{m}}$ RNA Mini Kit (Ambion) according to the manufacturer's instructions. For RT-qPCR, the RNA from all samples was used to obtain the viral titer and the $\beta$-actin mRNA amount, serving as an endogenous gene expression level.

IBV virus loads in Vero and BHK-21 cells were assessed in triplicate using RT-qPCR targeting the 5'UTR, as described by Callison et al. (2006) (400 nM IBV5'GU391 and IBV5'GL533 primers), with a Power SYBR ${ }^{\text {min }}$ Green RNA-to-CT ${ }^{\text {mox }}$ 1-Step Kit (Applied Biosystems) according to the manufacturer's instructions. For absolute quantification, a plasmid with a 5'UTR sequence was used to construct a ten-fold dilution standard curve from $10^{7}$ to $10^{3}$ copies, which resulted in a linear equation $(y=-3.357 x+38.05)$ with an $R^{2}$ value $=1.0$ and efficiency of $98.56 \%$. The absolute values (copies $/ \mu \mathrm{L}$ ) were calculated with normalization using $\beta$-actin mRNA from cells, with GoTaq ${ }^{\circledR}$ Probe 1-Step RT-qPCR (Promega) performed according to the manufacturer's instructions and with primers $(400 \mathrm{nM})$ and a probe $(150 \mathrm{nM})$ described by Ono et al. (2017).

Mean viral loads were tested for normality distribution with the Anderson-Darling test and the Mann-Whitney U test for comparison between the medians, with a critical p-value of 5\% using the nortest package (v.1.0.4) in the R program v.3.4.3 (2017) (R Core Team, 2015).

\section{Partial amplification and Sanger sequencing of S1 and nsp3}

Complementary DNAs (cDNAs) for all passages were synthesized with SuperScript ${ }^{\text {th }}$ III Reverse Transcriptase (Invitrogen) and Random Primers ${ }^{\mathrm{Tx}}$ (Invitrogen) and used for partial amplification of S1 and nsp3 with the high fidelity DNA polymerase AccuTaq ${ }^{\text {tx }}$ LA DNA Polymerase (Sigma-Aldrich) and with the primers described previously (Jones et al., 2005; Lin et al., 2004; Rossa et al., 2012).

Amplicons were purified with Illustra ${ }^{\mathrm{mm}}$ ExoproStar $^{\mathrm{Tw}}$ (GE Healthcare) or an Illustra ${ }^{\mathrm{ma}}$ GFX $^{\mathrm{mm}}$ PCR DNA and Gel Band Purification Kit (GE Healthcare), both according to the manufacturer's instructions, and submitted to bidirectional Sanger sequencing with BigDye $^{\mathrm{rm}}$ v3.1 (Applied Biosystems) according to the manufacturer's instructions in an ABI-3500 Genetic Analyzer (Applied Biosystems).

\section{Sequence analysis}

The chromatograms generated for each of the sense and antisense sequences were analyzed by the online Phred application available at Empresa Brasileira de Pesquisa Agropecuária (2018), and only positions with Phred scores $\geq 20$ were used. Each final sequence was generated with the Cap-contig application in the BioEdit program v.7.2.5 and submitted to BLASTn (Basic Local Alignment Search Tool) for sequencing confirmation at Basic Local Alignment Search Tool (BLAST, 2018).

The obtained partial S1 and nsp3 sequences were compared among passages for nucleotide and amino acid polymorphisms and identity locations after alignment using ClustalW multiple alignment in the BioEdit program v.7.2.5.

\section{Protein structure analysis}

Three-dimensional (3-D) models for the S1 protein region under analysis were inferred using the I-TASSER (Iterative Threading Assembly Refinement) algorithm available online at Zhang Lab (2018), choosing the models with the highest C-score (Zhang, 2008).

\section{Results}

\section{Passages of the Beaudette strain in Vero and BHK-21 cells}

IBV-induced syncytial cytopathic effect (CPE) was observed after $24 \mathrm{~h}$ post-inoculation for all passages in both Vero and BHK-21 cells, while no alterations were noticed in the monolayers of the negative controls. Examples of the CPE are shown in Figures 1 and 2.

\section{Viral loads}

In both Vero and BHK-21 cells, an oscillation in virus loads was observed throughout the 14 passages (Figures 3 and 4 and Table 1), but significant differences ( $\mathrm{p}=0.0156$ ) were detected only for median virus loads from the first to the $7^{\text {th }}$ passage and from the $8^{\text {th }}$ to the $14^{\text {th }}$ passage in Vero cells, which decreased from $7.36 \log$ to $5.44 \log$ the median values of IBV genome copies/ $\mu \mathrm{L}$ between these two series of passages.

\section{Molecular diversity analysis}

The sequences of the partial $\mathrm{S} 1$ subunit and nsp3 protein from the original inoculum can be found under the GenBank Accession numbers MK550892 and MK550893, respectively. The variant sequences were not submitted to avoid redundancy. 


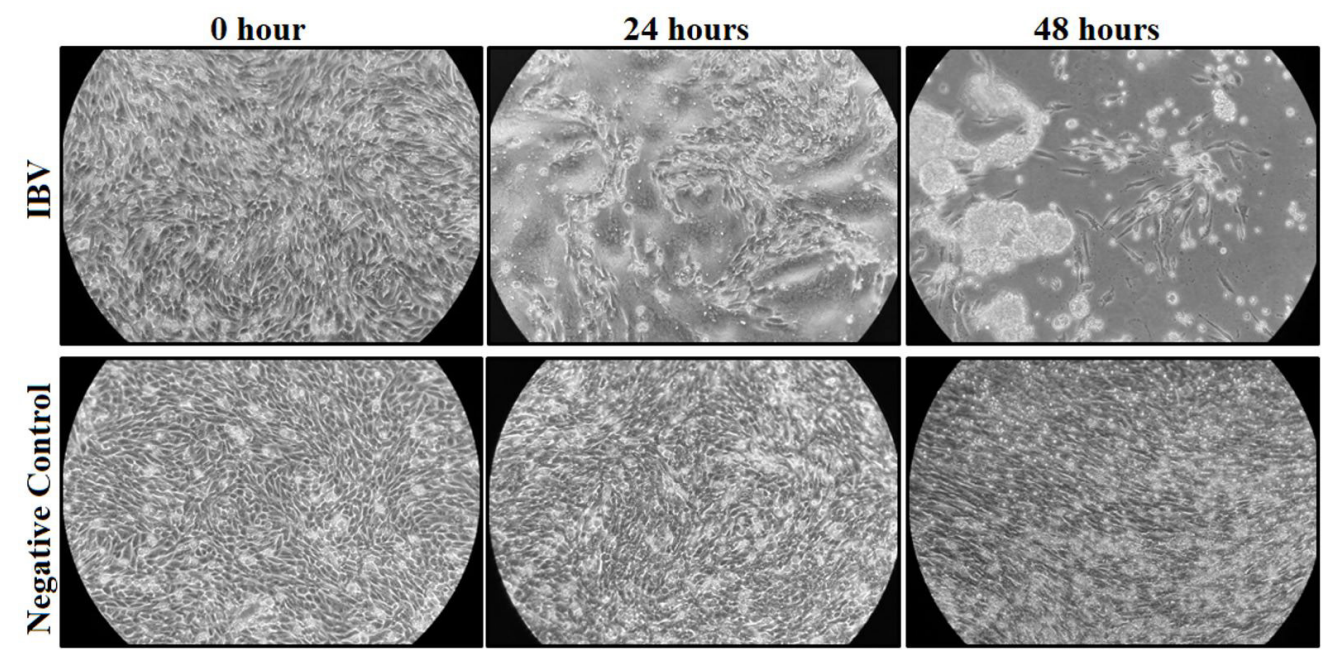

Figure 1 - CPE (cytopathic effect) after the inoculation of the Beaudette IBV strain in BHK-21 cells $\left(10^{\text {th }}\right.$ passage $)$ at 0,24 and $48 \mathrm{~h}$ post-inoculation (400x magnification); negative control corresponds to monolayers mock-infected with MEM.
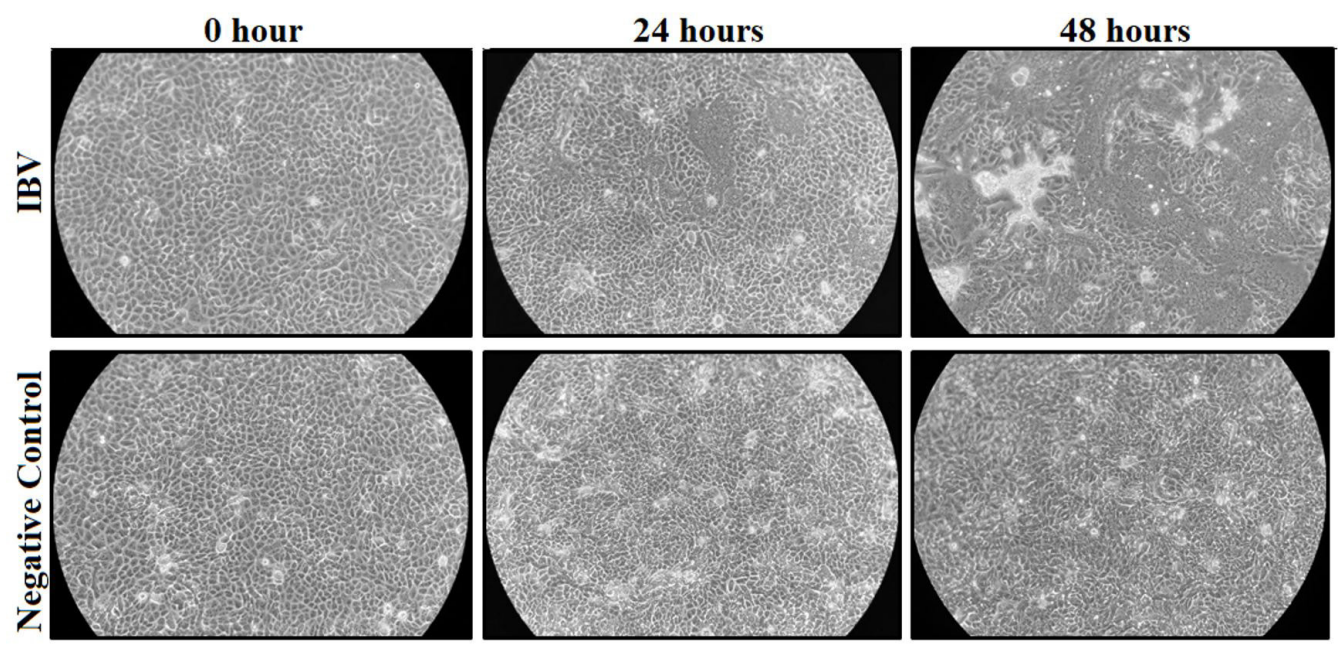

Figure $2-$ CPE (cytopathic effect) after the inoculation of the Beaudette IBV strain in Vero cells $\left(14^{\text {th }}\right.$ passage) at 0,24 and $48 \mathrm{~h}$ post-inoculation (400x magnification); negative control corresponds to monolayers mock-infected with MEM.

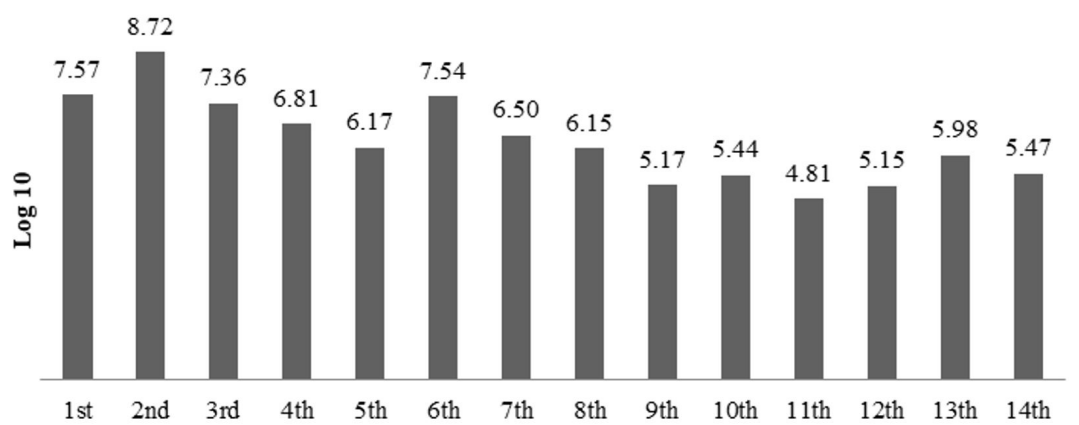

Figure 3 - IBV genome copy number per $\mu \mathrm{L}$ of sample of RNA, for the 14 passages of the Beaudette IBV strain in Vero cells.

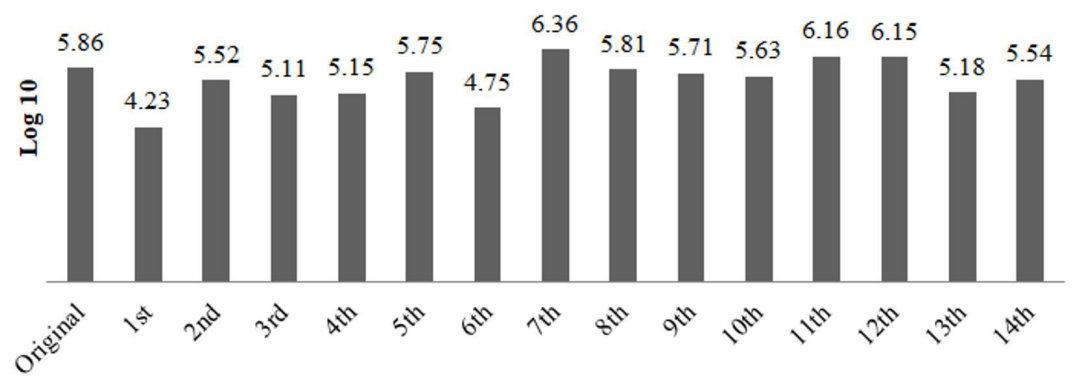

Figure 4 - IBV genome copy number per $\mu \mathrm{L}$ of sample of RNA, for the 14 passages of the Beaudette IBV strain in BHK-21 cells. Original refers to the embryonated chicken egg (ECE) inoculum. 


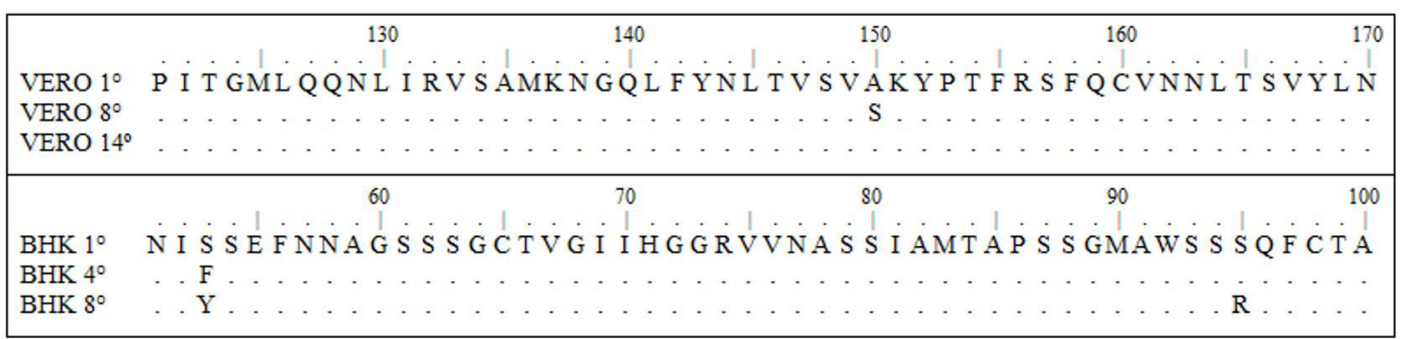

Figure 5 - Amino acid alignment of partial S1 gene, with mutations highlighted; Positions 131 to 170 and 51 to 100 on sequences from Vero and BHK-21, respectively (regarding GenBank accession number NC001451.1).

Table 1 - Median values of IBV genome copy numbers after passages of the Beaudette strain in Vero and BHK-21 cells

\begin{tabular}{cll} 
& \multicolumn{1}{c}{ BHK } & VERO \\
\hline $\mathbf{1}^{\text {st }}$ to $\mathbf{7}^{\text {th }}$ & 5.15 & 7.36 \\
$\mathbf{8}^{\text {th }}$ to $\mathbf{1 4}^{\text {th }}$ & 5.71 & 5.44 \\
\hline p-value & 0.1563 & 0.0156 \\
\hline
\end{tabular}

Table 2 - Mutations found after passages of the Beaudette strain in Vero and BHK-21 cells. Positions in reference to GenBank accession number: NC001451.1

\begin{tabular}{cccc}
\hline \multicolumn{4}{c}{ Spike gene mutations } \\
\hline Cell line & Cell passage & nt mutation & aa mutation \\
VERO & $8^{\text {th }}$ & G448T & A $150 \mathrm{~S}$ \\
& $14^{\text {th }}$ & T448G & S150A \\
BHK-21 & $4^{\text {th }}$ & C158T & S53F \\
& $8^{\text {th }}$ & T158A & F53Y \\
& $8^{\text {th }}$ & T285G & S95R \\
\hline
\end{tabular}

Table 3 - Degenerate positions found in chromatograms after partial S1 sequencing of the Beaudette IBV strain in Vero and BHK-21 cells; '>' for higher peaks and ' $~$ ' for visually similar

\begin{tabular}{cccc}
\hline \multirow{2}{*}{ Passages } & \multicolumn{2}{c}{ BHK-21 } & VERO \\
\cline { 2 - 4 } & aa 158 & aa $\mathbf{2 8 5}$ & aa 448 \\
\hline 1 & $\mathrm{C}$ & $\mathrm{T}$ & $\mathrm{G}$ \\
2 & $\mathrm{Y}(\mathrm{C}>\mathrm{T})$ & $\mathrm{T}$ & $\mathrm{G}$ \\
3 & $\mathrm{Y}(\mathrm{C} \sim \mathrm{T})$ & $\mathrm{T}$ & $\mathrm{G}$ \\
4 & $\mathrm{Y}(\mathrm{T}>\mathrm{C})$ & $\mathrm{T}$ & $\mathrm{G}$ \\
5 & $\mathrm{Y}(\mathrm{T}>\mathrm{C}>\mathrm{A})$ & $\mathrm{T}$ & $\mathrm{G}$ \\
6 & $\mathrm{~T}$ & $\mathrm{~T}$ & $\mathrm{~K}(\mathrm{G}>\mathrm{T})$ \\
7 & $\mathrm{~W}(\mathrm{~T}>\mathrm{A})$ & $\mathrm{T}$ & $\mathrm{K}(\mathrm{G}>\mathrm{T})$ \\
8 & $\mathrm{~W}(\mathrm{~A}>\mathrm{T})$ & $\mathrm{K}(\mathrm{G}>\mathrm{T})$ & $\mathrm{K}(\mathrm{T}>\mathrm{G})$ \\
9 & $\mathrm{~A}$ & $\mathrm{G}$ & $\mathrm{K}(\mathrm{T}>\mathrm{G})$ \\
10 & $\mathrm{~A}$ & $\mathrm{G}$ & $\mathrm{K}(\mathrm{T}>\mathrm{G})$ \\
11 & $\mathrm{~A}$ & $\mathrm{G}$ & $\mathrm{K}(\mathrm{T}>\mathrm{G})$ \\
12 & $\mathrm{~A}$ & $\mathrm{G}$ & $\mathrm{K}(\mathrm{G} \sim \mathrm{T})$ \\
13 & $\mathrm{~A}$ & $\mathrm{G}$ & $\mathrm{K}(\mathrm{G} \sim \mathrm{T})$ \\
14 & $\mathrm{~A}$ & $\mathrm{G}$ & $\mathrm{K}(\mathrm{G}>\mathrm{T})$ \\
\hline
\end{tabular}

No polymorphisms were found for nsp 3 for any of the passages and cell lines, but regarding S1, not only amino acid substitutions, but also minor variants could be detected on the chromatograms in fluctuating intensities at the mutated positions (Tables 2 and 3 ).

In Vero cells, the $8^{\text {th }}$ passage showed a G448T nucleotide substitution on the spike gene, resulting in an A150S amino acid substitution that reverted to the original state at passage 14 . As seen in Table 3 , the variant with a thymine at position 448 gradually peaked in frequency,

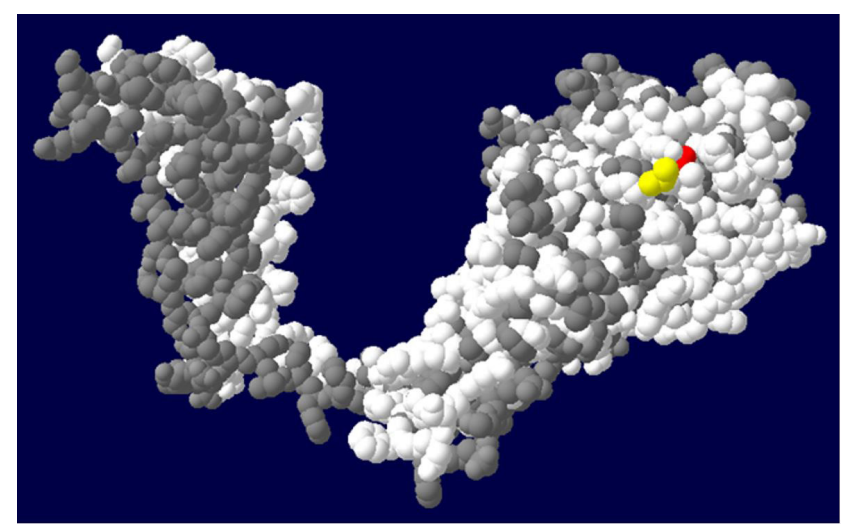

Figure 6-Tertiary protein structures from partial S1 subunit of S gene of the Beaudette strain of IBV (nt 42 to 863 ; aa 28 to 287) at Vero passages 7 (white) and 8 (dark gray), and the amino acids mutation in positions 150 , yellow (alanine) and red (serine), for these respective passages. Positions in reference to GenBank accession number: NC001451.1.

appearing on chromatograms at the $6^{\text {th }}$ passage and becoming dominant, while the variant with a guanine at position 488 showed decreasing chromatogram peak frequencies and reverted to the original dominant state only at the $14^{\text {th }}$ passage.

In the Vero cell passages, there was a constant alternation between variants based on chromatogram peaks, and different from the BHK-21 cell passages, spike gene mutations did not revert to the original states at higher passages (Tables 2 and 3); a C158T nucleotide substitution in the $4^{\text {th }}$ passage led to a S53F amino acid substitution, and T158A in the $8^{\text {th }}$ passage led to a F53Y amino acid substitution, while at position 285 in the $8^{\text {th }}$ passage, a T285G nucleotide substitution led to a S95R aa substitution (Figure 5).

\section{Protein structure analysis}

Protein structure prediction was carried out with partial S1 sequences corresponding only to passages in which mutations were found, i.e., Vero cell passages seven and eight (A150S) and BHK-21 cell passages three, four and eight (S53F, F53Y and S95R), and resulted in local changes in protein folding, as shown in Figures 6 and 7, with no apparent global consequences for S1 monomers. 


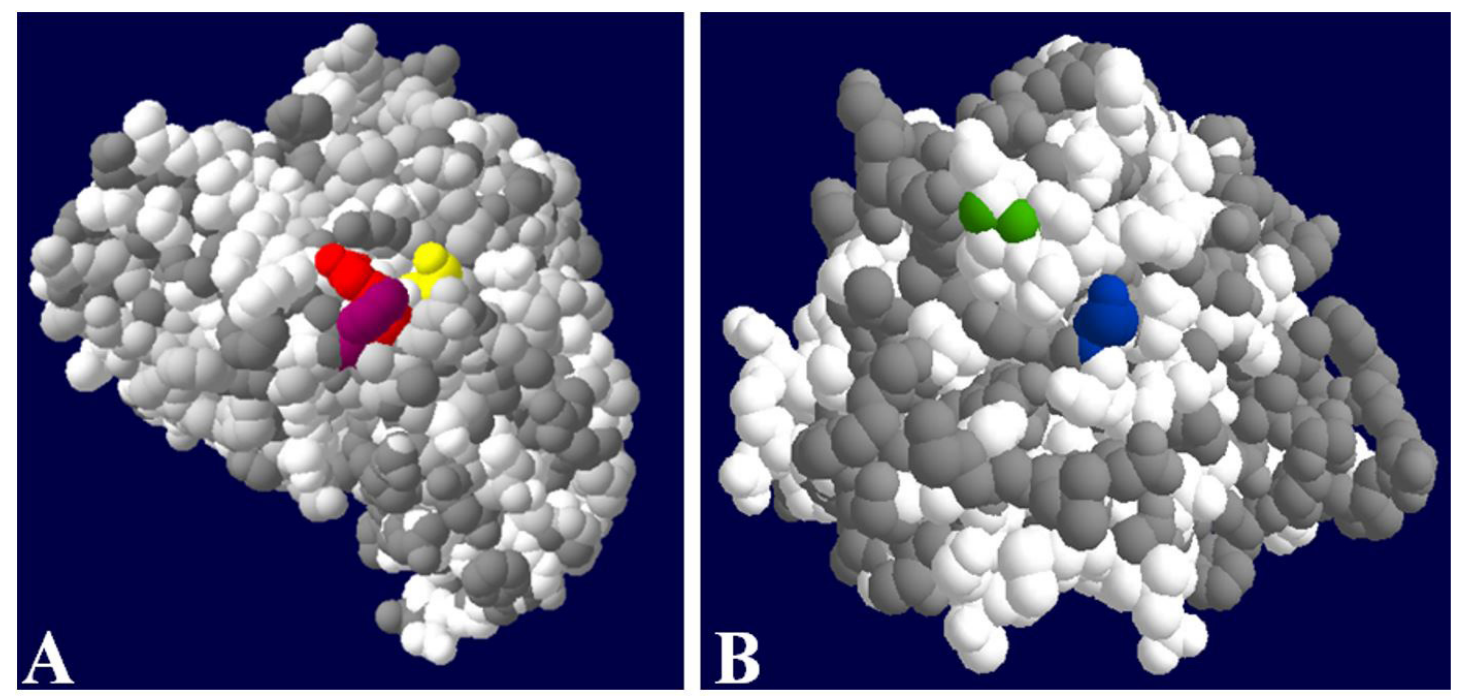

Figure 7 - Tertiary protein structures from partial S1 subunit of S gene of the Beaudette strain of IBV (nt 43 to 671 ; aa 15 to 223) at BHK-21 passages 3 (white), 4 (light gray) and 8 (dark gray); (A) point mutations in position 53, serine (yellow), phenylalanine (purple) and tyrosine (red), respectively; (B) point mutations in position 95, serine (blue) and arginine (green), respectively. Positions in reference to GenBank accession number: NC001451.1.

\section{Discussion}

The ability of the Beaudette strain to grow efficiently and cause CPE (cytopathic effect) in Vero (African green monkey kidney) and BHK-21 (baby hamster kidney) cells has long been established (Cunningham et al., 1972; Coria \& Ritchie, 1973; Otsuki et al., 1979) and is often used in IBV studies (Cook et al., 2012). In the present study, the Beaudette strain was subjected to 14 passages in both mammalian cell lines to assess IBV evolution under different habitats.

Although the original inoculum used in this study was derived from an embryonated chicken egg (ECE) passage, CPE was evident starting at passage 1 in both cell lines. The typical CPE for coronaviruses in cell culture, with the formation of syncytia, cell rounding and consequently cell lysis (Liu et al., 2001), was clearly detected in Vero and BHK-21 cells (Figures 1 and 2), with no noticeable differences among passages and cell lines.

The first emergence of CPE for the Beaudette strain in Vero cells has been reported only at passage 4 (Fang et al., 2005), while in BHK-21 cells, it has been reported with $60 \mathrm{~h}$ after inoculation (Otsuki et al., 1979). Thus, differences in the volume and titer of the starting inoculum and the number of cells in the monolayers could have resulted in the earlier emergence of CPE detected during this study.

Nonetheless, the first passage in BHK-21 cells showed a decrease in virus load from $5.86 \log$ genome copies/ $\mu \mathrm{L}$ in the original ECE inoculum to $4.23 \log$ genome copies $/ \mu \mathrm{L}$, while the $1^{\text {st }}$ passage in Vero cells using the $1^{\text {st }}$ passage in BHK-21 cells as an inoculum showed a virus load of $7.57 \mathrm{log}$ genome copies/ $\mu \mathrm{L}$. This initial increased fitness in Vero cells is probably due to the presence of preselected variants in the quasispecies, as evidenced by the high adaptability of the Beaudette strain to Vero cells (Fang et al., 2005; Wickramasinghe et al., 2011).

From the first passages on, virus loads in both Vero and BHK-21 cells oscillated as a possible consequence of a balance between virus loads and cell lysis rates, leading to optimized virus spreading to new cells (Liu et al., 2001). Moderate virulence with high transmissibility results in a successful spread among the host population (Toro et al., 2012b) and was thus advantageous for these virus populations.

These phenotypical traits were not based in the nsp 3 region focused on in this study, as no polymorphic sites were found among all passages. Attenuation of the Beaudette strain can be tracked to the replicase polyprotein, which includes nsp3 and an additional 14 NSPs, especially nsp3, as this protein may have a role in pathogenicity (Armesto et al., 2009; Phillips et al., 2012).

On the other hand, although nsp3 contains the active PLpro site that cleaves the $\mathrm{N}$-terminal region (between NSPs 2-3 and 3-4) of the replicase polyprotein (Ziebuhr et al., 2000) and, thus, a relatively conserved sequence due to high structural constraint expected for this region, replication might not be affected by some mutations in nsp3 (Keep et al., 2018).

However, for the partial region of the $\mathrm{S} 1$ subunit of the $S$ protein, nonsynonymous mutations and minor variants were found when the different passages were compared. This result is relevant, as $\mathrm{S} 1$ is responsible for IBV tropism (Casais et al., 2003) because it harbors the receptor-binding domain (RBD) (Promkuntod et al., 2014) and plays a role in pathogenicity (Ziebuhr et al., 2000), with a high 
level of variation among IBV strains (Casais et al., 2003; Wickramasinghe et al., 2011; Shan et al., 2018).

Specific signatures in S1 have been described as responsible for the ability of the Beaudette strain to grow in Vero cells (Bickerton et al., 2018), and even a single amino acid change in $S 1$ can affect the infectivity of this strain (Promkuntod et al., 2014; Shan et al., 2018). Furthermore, there is evidence that the $S$ gene displays the most frequent recombination breakpoints responsible for the spillover of SARS (Cui et al., 2019; Shan et al., 2018).

The nonsynonymous mutations found in this study map are within the RBD, but only those in position 53 of passages in BHK-21 cells are within the region considered determinant for receptor binding, named the HVR (hypervariable region) I (Promkuntod et al., 2014; Leyson et al., 2016; Shan et al., 2018). However, all the mutations found in this study did not agree with the mutations found in other studies with the Beaudette strain in Vero cells (Armesto et al., 2009; Bickerton et al., 2018; Fang et al., 2005; Shan et al., 2018; Youn et al., 2005).

The presence of minor variants is a characteristic of RNA viruses due to imperfect proofreading during replication, which results in a quasispecies population pattern after the accumulation of genomic mutations (Domingo et al., 2012). Jackwood et al. (2003) found quasispecies in Beaudette based on different melting peaks after RT-qPCR, but chromatogram peak-based quasispecies detection has also been reported for IBV (Toro et al., 2012b).

As seen in Table 3, quasispecies reverted to the original state observed in the ECE strain at passage 12 in Vero cells based on nt 448, but in BHK-21 cells, no reversion was found after passage 8 . This diverse evolution in BHK-21 cells compared to that in Vero cells could be a further consequence of the already mentioned enhanced adaptability of the Beaudette strain in Vero cells and could result in fine-tuning of the quasispecies to the sialic acid receptors found in different cell types, as mutations in S1 have already been associated with the adaptation of AvCoV during passaging from chickens to embryos and back (Leyson et al., 2016; Winter et al., 2006; Li, 2016).

However, it is worth mentioning that in this study, a limited number of passages was carried out, which narrows the potential broadened understanding of the time and mode of IBV evolution and selection pressures for quasispecies, the target of natural selection for RNA viruses.

Partial S1 3-D modeling (Figures 6 and 7) showed local alterations in protein structure, which were most evident regarding aa residue 95 for the BHK-21 cell passages (Figure 7B). Considering that the spike is a trimer (Li, 2016; Walls et al., 2016), minor local structural changes could have their consequences amplified when the quaternary structure is considered.

While an indication of quasispecies evolution and markers of adaptation possibly related to the adaptation of the Beaudette strain to different cell lines was obtained during this study, it must be considered that only a fraction of nsp3 and the $\mathrm{S}$ gene has been sequenced for a limited number of passages and was based on Sanger sequencing only. Whole-genome high-throughput sequencing would allow an in-depth view with increased sensitivity not only of genetic markers for in vitro evolution but also of quasispecies.

In conclusion, IBV evolution takes different routes depending on the host cell, with detectable fluctuations in quasispecies affecting virus fitness as measured by virus loads.

\section{Conflict of Interest}

None.

\section{Ethical Statement}

This experiment was approved by the Ethics Committee on the Use of Animals of the School of Veterinary Medicine, University of São Paulo, under the registration $n^{\circ} 2050020517$. This article does not contain any studies with human participants performed by any of the authors.

\section{Acknowledgements}

Authors thank CNPq (Brazilian National Board of Scientific and Technological Development), grant numbers 307291/20170 and 400604/2016-7, and CAPES (Coordination for the Improvement of Higher Education Personnel, Brazil) for funding this work.

\section{References}

Armesto M, Cavanagh D, Britton P. The replicase gene of avian coronavirus infectious bronchitis virus is a determinant of pathogenicity. PLoS One. 2009;4(10):e7384. http://dx.doi. org/10.1371/journal.pone.0007384. PMid:19816578.
Bickerton E, Maier HJ, Stevenson-Leggett P, Armesto M, Britton $P$. The $S 2$ subunit of infectious bronchitis virus Beaudette is a determinant of cellular tropism. 2018;92(19):e01044-18. http:// dx.doi.org/10.1128/JVI.01044-18. PMid:30021894. 
BLAST: Basic Local Alignment Search Tool [Internet]. Bethesda: BLAST; 2018 [cited 2020 Jan 28]. Available from: http://www.ncbi.nlm.nih.gov/BLAST/

Callison SA, Hilt DA, Boynton TO, Sample BF, Robison R, Swayne DE, Jackwood MW. Development and evaluation of a real-time Taqman RT-PCR assay for the detection of infectious bronchitis virus from infected chickens. J Virol Methods. 2006;138(1-2):60-5. http://dx.doi.org/10.1016/j. jviromet.2006.07.018. PMid:16934878.

Casais R, Dove B, Cavanagh D, Britton P. Recombinant avian infectious bronchitis virus expressing a heterologous spike gene demonstrates that the spike protein is a determinant of cell tropism. J Virol. 2003;77(16):9084-9. http://dx.doi. org/10.1128/JVI.77.16.9084-9089.2003. PMid:12885925.

Cavanagh D. Coronavirus avian infectious bronchitis virus. Vet Res. 2007;38(2):281-97. http://dx.doi.org/10.1051/ vetres:2006055. PMid:17296157.

Colvero LP, Villarreal LY, Torres CA, Brañdo PE. Assessing the economic burden of avian infectious bronchitis on poultry farms in Brazil. OIE Rev Sci Tech. 2015;34(3):993-9. http://dx.doi.org/10.20506/ rst.34.3.2411. PMid:27044167.

Cook JKA, Jackwood M, Jones RC. The long view: 40 years of infectious bronchitis research. Avian Pathol. 2012;41(3):239-50. http://dx.doi.org/10.1080/03079457.2 012.680432. PMid:22702451.

Coria MF, Ritchie AE. Serial passage of 3 strains of avian infectious bronchitis virus in african green monkey kidney cells (VERO). Avian Dis. 1973;17(4):697-704. http://dx.doi. org/10.2307/1589036. PMid:4203249.

Cui J, Li F, Shi ZL. Origin and evolution of pathogenic coronaviruses. Nat Rev Microbiol. 2019;17(3):18192. http://dx.doi.org/10.1038/s41579-018-0118-9. PMid:30531947.

Cunningham CH, Spring MP, Nazerian K. Replication of avian infectious bronchitis virus in african green monkey kidney cell line VERO. J Gen Virol. 1972;16(3):423-7. http:// dx.doi.org/10.1099/0022-1317-16-3-423. PMid:4627930.

Domingo E, Sheldon J, Perales C. Viral quasispecies evolution. Microbiol Mol Biol Rev. 2012;76(2):159-216. http://dx.doi.org/10.1128/MMBR.05023-11. PMid:22688811.
Empresa Brasileira de Pesquisa Agropecuária. Electropherogram quality analysis [Internet]. Brasília: EMBRAPA; 2018 [cited 2020 Jan 28]. Available from: http://asparagin.cenargen. embrapa.br/phph/

Fang SG, Shen S, Tay FPL, Liu DX. Selection of and recombination between minor variants lead to the adaptation of an avian coronavirus to primate cells. Biochem Biophys Res Commun. 2005;336(2):417-23. http://dx.doi.org/10.1016/j. bbrc.2005.08.105.

International Committee on Taxonomy of Viruses. ICTV Taxonomy history: avian coronavirus [Internet]. USA: ICTV; 2018 [cited 2020 Jan 28]. Available from: https://talk.ictvonline. org/taxonomy/p/taxonomy-history?taxnode_id=20181880

Jackwood MW, Hilt DA, Callison SA. Detection of infectious bronchitis virus by real-time reverse transcriptase-polymerase chain reaction and identification of a quasispecies in the Beaudette strain. Avian Dis. 2003;47(3):718-24. http:// dx.doi.org/10.1637/6075. PMid:14562902.

Jones RC, Worthington KJ, Capua I, Naylor CJ. Efficacy of live infectious bronchitis vaccine against a novel European genotype, Italy 02. VetRec. 2005;156(20):646-7. http:// dx.doi.org/10.1136/vr.156.20.646.

Keep S, Bickerton E, Armesto M, Britton P. The ADRP domain from a virulent strain of infectious bronchitis virus is not sufficient to confer a pathogenic phenotype to the attenuated beaudette strain. J Gen Virol. 2018;99(8):1097102. http://dx.doi.org/10.1099/jgv.0.001098. PMid:29893665.

Laconi A, van Beurden SJ, Berends AJ, Krämer-Kühl A, Jansen CA, Spekreijse D, Chénard G, Philipp HC, Mundt E, Rottier PJM, Hélène Verheije M. Deletion of accessory genes $3 \mathrm{a}, 3 \mathrm{~b}, 5 \mathrm{a}$ or $5 \mathrm{~b}$ from avian coronavirus infectious bronchitis virus induces an attenuated phenotype both in vitro and in vivo. J Gen Virol. 2018;99(10):1381-90. http:// dx.doi.org/10.1099/jgv.0.001130. PMid:30067172.

Leyson CLM, Jordan BJ, Jackwood MW. Insights from molecular structure predictions of the infectious bronchitis virus S1 spike glycoprotein. Infect Genet Evol. 2016;46:124-9. http:// dx.doi.org/10.1016/j.meegid.2016.11.006. PMid:27836775.

Li F. Structure, function, and evolution of coronavirus spike proteins. Annu Rev Virol. 2016;3(1):237-61. http:// dx.doi.org/10.1146/annurev-virology-110615-042301 . PMid:27578435. 
Lin Tl, Loa CC, Wu CC. Complete sequences of 3' end coding region for structural protein genes of Turkey coronavirus. Virus Res. 2004;106(1):61-70. http://dx.doi.org/10.1016/j. virusres.2004.06.003.

Liu C, Xu HY, Liu DX. Induction of caspase-dependent apoptosis in cultured cells by the avian coronavirus infectious bronchitis virus. J Virol. 2001;75(14):6402-9. http://dx.doi. org/10.1128/JVI.75.14.6402-6409.2001. PMid:11413307.

Nikfarjam L, Farzaneh P. Prevention and detection of mycoplasma contamination in cell culture. Cell J. 2012;13(4):203-12. PMid:23508237.

Ono EAD, Taniwaki SA, Brandão P. Short interfering RNAs targeting a vampire-bat related rabies virus phosphoprotein mRNA. Braz J Microbiol. 2017;48(3):566-9. http://dx.doi. org/10.1016/j.bjm.2016.11.007. PMid:28223028.

Otsuki K, Noro K, Yamamoto H, Tsubokura M. Studies on avian infectious bronchitis virus (IBV) II. Propagation of IBV in several cultured cells. Arch Virol. 1979;60(2):115-22. http://dx.doi.org/10.1007/ BF01348027. PMid:226034.

Phillips JE, Jackwood MW, McKinley ET, Thor SW, Hilt DA, Acevedol ND, Williams SM, Kissinger JC, Paterson AH, Robertson JS, Lemke C. Changes in nonstructural protein 3 are associated with attenuation in avian coronavirus infectious bronchitis virus. Virus Genes. 2012;44(1):63-74. http://dx.doi.org/10.1007/s11262-0110668-7. PMid:21909766.

Promkuntod N, van Eijndhoven REW, de Vrieze G, Gröne A, Verheije MH. Mapping of the receptor-binding domain and amino acids critical for attachment in the spike protein of avian coronavirus infectious bronchitis virus. Virology. 2014;448:26-32. http://dx.doi.org/10.1016/j.virol.2013.09.018. PMid:24314633.

R Core Team. R: a language and environment for statistical computing. Vienna, Austria: R Foundation for Statistical Computing; 2015 [cited 2020 Jan 28]. Available from: http:// www.R-project.org/

Rossa GAR, Torres CA, Villarreal LYB, Silva SOS, Richtzenhain LJ, Brandão PE. On the diversity of papain-like and nsp2 genes of Brazilian strains of infectious bronchitis virus. In: Proceedings of the VII International Symposium on Avian Corona- and Pneumoviruses and Complicating Pathogens; 2012 June 18-21; Rauischolzhausen, Germany. USA: Web of Science Group; 2012. p. 98-109.
Shan D, Fang S, Han Z, Ai H, Zhao W, Chen Y, Jiang L, Liu S. Effects of hypervariable regions in spike protein on pathogenicity, tropism, and serotypes of infectious bronchitis virus. Virus Res. 2018;250:104-13. http://dx.doi. org/10.1016/j.virusres.2018.04.013. PMid:29684409.

Sjaak de Wit JJ, Cook JK, van der Heijden HM. Infectious bronchitis virus variants: a review of the history, current situation and control measures. Avian Pathol. 2011;40(3):22335. http://dx.doi.org/10.1080/03079457.2011.566260. PMid:21711181.

Toro H, Pennington D, Gallardo RA, van Santen VL, van Ginkel FW, Zhang J, Joiner KS. Infectious bronchitis virus subpopulations in vaccinated chickens after challenge. Avian Dis. 2012a;56(3):501-8. http://dx.doi.org/10.1637/9982110811-Reg.1. PMid:23050466.

Toro H, van Santen VL, Jackwood MW. Genetic diversity and selection regulates evolution of infectious bronchitis virus. Avian Dis Dig. 2012b;56(3):449-55. http://dx.doi. org/10.1637/10072-020212-Review.1. PMid:23050459.

Walls AC, Tortorici MA, Bosch BJ, Frenz B, Rottier PJM, DiMaio F, Rey FA, Veesler D. Cryo-electron microscopy structure of a coronavirus spike glycoprotein trimer. Nature. 2016;531(7592):114-7. http://dx.doi.org/10.1038/ nature16988. PMid:26855426.

Wickramasinghe INA, de Vries RP, Grone A, de Haan CAM, Verheije MH. Binding of avian coronavirus spike proteins to host factors reflects virus tropism and pathogenicity. J Virol. 2011;85(17):8903-12. http://dx.doi.org/10.1128/ JVI.05112-11. PMid:21697468.

Winter C, Schwegmann-Weßels C, Cavanagh D, Neumann U, Herrler G. Sialic acid is a receptor determinant for infection of cells by avian Infectious bronchitis virus. J Gen Virol. 2006;87(Pt 5):1209-16. http://dx.doi.org/10.1099/ vir.0.81651-0. PMid:16603523.

Yamada Y, Liu XB, Fang SG, Tay FPL, Liu DX. Acquisition of cell-cell fusion activity by amino acid substitutions in spike protein determines the infectivity of a coronavirus in cultured cells. PLoS One. 2009;4(7):e6130. http://dx.doi. org/10.1371/journal.pone.0006130. PMid:19572016.

Youn S, Leibowitz JL, Collisson EW. In vitro assembled, recombinant infectious bronchitis viruses demonstrate that the $5 \mathrm{a}$ open reading frame is not essential for replication. Virology. 2005;332(1):206-15. http://dx.doi.org/10.1016/j. virol.2004.10.045. PMid:15661153. 
Young L, Sung J, Stacey G, Masters JR. Detection of mycoplasma in cell cultures. Nat Protoc. 2010;5(5):929-34. PMid:20431538.

Zhang Lab [Internet]. Ann Arbor: Zhang Lab; 2018 [cited 2020 Jan 28]. Available from: http://zhanglab.ccmb.med. umich.edu/I-TASSER

Zhang Y. I-TASSER server for protein 3D structure prediction. BMC Bioinformatics. 2008;9(1):40. http://dx.doi. org/10.1186/1471-2105-9-40. PMid:18215316.

Ziebuhr J, Gorbalenya AE, Snijder EJ. Virus-encoded proteinases and proteolytic processing in the Nidovirales. J Gen
Virol. 2000;81(Pt 4):853-79. http://dx.doi.org/10.1099/00221317-81-4-853. PMid:10725411.

Financial Support: This work was funded by $\mathrm{CNPq}$ (Brazilian National Board for Scientific and Technological Development), grant numbers 307291/2017-0 and 400604/20167, and CAPES (Coordination for the Improvement of Higher Education Personnel, Brazil), finance code 001, which had no role in study design; collection, analysis and interpretation of data; report writing, or decision to submit the article for publication. 